\title{
KELAYAKAN FINANSIAL TANAMAN KAYU UNTUK MEMANFAATKAN LAHAN YANG KURANG SESUAI UNTUK KARET
}

\author{
(Financial Feasibility of Timber Plant to Use Marginally Suitable Land for Rubber)
}

Titik Widyasari ${ }^{1}$ dan Uhendi Haris ${ }^{2}$

${ }^{1}$ Balai Penelitian Getas (Pusat Penelitian Karet) J1. Patimura km. 6 Po Box 804, Salatiga 50702

${ }^{2}$ Holding Perkebunan Nusantara, PT Perkebunan Nusantara III (Persero) Gedung Agro Plaza Lt 15, J1. HR Rasuna Said Kav. X2 No.1, Kuningan,Jakarta.

Email : titikwidyasari@puslitkaret.co.id

Diterima 5 Oktober 2017 / Direvisi 14 Maret 2018 / Disetujui 10 April 2018

\begin{abstract}
Abstrak
Kondisi lahan salah satu perkebunan karet di Jawa Tengah memiliki kelas kesesuaian lahan yang bervariasi untuk tanaman karet. Terdapat $25,2 \%$ yang termasuk dalam kelas kurang sesuai dan tidak sesuai. Lahan dengan kondisi tersebut akan optimal jika ditanami komoditas yang sesuai. Komoditas alternatif yang dinilai prospektif dikembangkan adalah tanaman kayu seperti sengon, jabon dan akasia. Penelitian ini bertujuan untuk memperoleh gambaran tentang kelayakan secara finansial pengusahaan tanaman kayu sebagai komoditas alternatif untuk mengoptimalkan lahan perkebunan berbasis karet. Penelitian ini dilakukan di beberapa perkebunan karet di Provinsi Jawa Tengah pada bulan Februari - Desember 2016. Metode penelitian yang digunakan adalah metode survei dengan cara memilih sampel secara purposive pada 12 kebun berbasis tanaman karet. Data penelitian dianalisis dengan menggunakan metode penelitian deskriptif dan kuantitatif. Hasil penelitian menunjukkan bahwa ketiga jenis tanaman kayu (sengon, jabon dan akasia) secara finansial layak untuk dikembangkan dengan nilai net present value sebesar Rp 6 juta - Rp 25 juta, internal rate of return $21 \%$ - 34\%, gross benefit cost ratio 1,4 - 2,3, dan revenue cost ratio 2,2 - 4,5. Hasil uji sensitivitas menunjukkan bahwa ketiga tanaman tidak sensitif terhadap perubahan biaya dan harga jual. Pada saat tekanan ekonomi biaya naik 10\% - 30\% dan harga turun
\end{abstract}

$10 \%$ - 30\%, baik secara terpisah maupun bersama-sama, diperoleh nilai $\mathrm{R} / \mathrm{C}>1$. Dengan demikian, sengon, jabon dan akasia merupakan tanaman alternatif yang prospektif untuk optimalisasi pemanfaatan lahan perkebunan berbasis karet.

Kata kunci : karet, kayu, kelayakan finansial, pemanfaatan lahan

\section{Abstract}

Condition of land in one of rubber plantation in Central Java has varied land suitability class to plant rubber.There are $25,2 \%$ are included in the class marginally suitable and not suitable. Land with these conditions will be optimal if planted with suitable commodity. Alternative commodities rated prospective developed is a wood plant such as albazia, jabon, and acasia. This research aims to gain an overview of the financial feasibility of cultivation of wood plant as alternative commodities to optimize the land use rubber based plantation. This research was conducted at several rubber plantations in Central Java province in FebruaryDecember 2016. The research method used was survey methode by selecting samples are purposive in 12 rubber based plantation.Research data were analyzed using descriptive and quantitative methods. The result showed that these three types of wood plants (albazia, jabon, and acasia) were financialy feasible to be developed with the net present value of $R p 6$ million - Rp 25 million, internal rate of return $21 \%-34 \%$, gross benefit cost ratio $1.4-2.3$ and revenue cost ratio $2.2-4.5$. The 
sensitivity test results showing that a third of plant is not sensitive to changes in cost and selling price. At a time when economic pressures cost up 10\%-30\% and timber prices fell 10-30\% either separately or simultaneously, the value of $R / C>1$. Thus, albazia, jabon, and acacia plants prospective alternatives for optimization the land use in rubber based plantation.

Keywords : rubber,wood plant, financial feasibility, land use

\section{Pendahuluan}

Lahan perkebunan berbasis karet jika dikaji tingkat kelayakan lahannya memiliki spektrum kelas kesesuaian lahan yang berbeda untuk tanaman karet. Pada umumnya terdapat lahan dengan kategori sangat sesuai (S1), cukup sesuai (S2), kurang sesuai (S3) hingga tidak sesuai (NS) untuk tanaman karet. Pada kasus salah satu perusahaan di Jawa Tengah, terdapat lahan dengan kategori kurang sesuai (S3) dan tidak sesuai (NS). Kondisi optimal pemanfaatan lahan demikian akan tercapai jika lahan tersebut ditanami komoditas lain yang lebih sesuai untuk lahan tersebut. Salah satu alternatif yang dinilai prospektif untuk dikembangkan adalah tanaman kayu. Menurut Krisnawati et al. (2011), sengon merupakan salah satu tanaman kayu yang memiliki nilai ekonomis tinggi, tingkat pertumbuhan sangat cepat dan mampu beradaptasi dengan berbagaijenis tanah.

Dinamika harga karet pada kondisi lemah seperti saat ini, diperlukan alternatif tambahan pendapatan dari usaha lainnya yang prospektif. Pada kondisi harga karet yang rendah, diperlukan budidaya kayu pada lahan perkebunan berbasis karet yang menjadi alternatif yang sangat baik dan prospektif untuk meningkatkan kinerja finansial usaha perkebunan berbasis karet. Potensi pengembangan kayu cukup besar karena perawatan yang relatif mudah, intensitas pengambilan hasil hanya di masa akhir (6 - 8 tahun) tidak serutin tanaman karet, kebutuhan tenaga kerja lebih rendah daripada karet dan bernilai ekonomi tinggi.
Pada tahun 2015, Pulau Jawa merupakan pulau terpadat dengan jumlah penduduk mencapai 145 juta penduduk (Badan Pusat Statistik, 2014), sehingga kebutuhan kayu juga meningkat. Nasendi (1984) memproyeksikan permintaan kayu di Jawa pada tahun 2020 sebesar 199,110 juta $\mathrm{m}^{3}$ /tahun. Permintaan kayu semakin meningkat untuk berbagai keperluan dan tidak diiringi dengan produksi kayu yang memadai. Hal tersebut menjadi peluang untuk mengembangkan kayu di lahan yang tidak sesuai untuk karet terutama di lahan milik perkebunan berbasis karet.

Hutan telah mengalami degradasi dengan laju 1,8 juta per tahun sehingga tidak mampu menjadi pemasok kayu utama sebagai bahan industri (Hardiatmi, 2010). Perkembangan industri kayu sangat progresif sehingga terjadi ketidakseimbangan hutan sebagai pemasok kayu bahan baku industri, dengan kapasitas terpasang $2.338 .297 \mathrm{~m}^{3}$, namun yang tersuplai hanya $1.394 .362 \mathrm{~m}^{3}$. Jika rendemen sekitar $50 \%$, seharusnya diperlukan bahan baku sejumlah $4.676 .594 \mathrm{~m}^{3}$ sehingga terjadi defisit sekitar 3 juta $\mathrm{m}^{3} /$ tahun(Subari, 2014).

Puslit Karet telah melakukan kajian di perkebunan berbasis karet yang tersebar di Jawa Tengah seluas 29.646,88 Ha. Hasil kajian tersebut menunjukkan bahwa terdapat lahan yang kurang prospektif untuk tanaman karet sebesar $25,2 \%$. Lahan yang kurang prospektif tersebut terdiri dari kelas kesesuaian lahan S3 seluas 7.203,59 Ha dan NS seluas 264,26 Ha (Pusat Penelitian Karet, 2016). Kondisi pemanfaatan lahan yang kurang sesuai untuk tanaman karet akan optimal jika dimanfaatkan untuk komoditas lainnya. Salah satu alternatif yang dinilai prospektif untuk dikembangkan adalah tanaman kayu. Lahan yang kurang prospektif untuk tanaman karet, pada umumnya menghasilkan pendapatan yang rendah akibat pertumbuhan tanaman yang tidak optimal, produktivitas karet yang rendah, dan mundurnya umur matang sadap (buka sadap lebih dari 5 tahun). Selain itu juga produktivitas lahan berpengaruh terhadap harga pokok. Menurut (Widyasari \& Rouf, 2017) produktivitas karet yang rendah akan mengakibatkan harga pokok menjadi tinggi. 
Jika hal tersebut terjadi, maka akan berakibat buruk bagi keberlanjutan perusahaan.

Tulisan ini bertujuan untuk memperoleh gambaran kelayakan tanaman kayu seperti sengon, jabon dan akasia sebagai salah satu alternatif dalam optimalisasi pemanfaatan lahan dan pendapatan usaha perkebunan berbasis karet yang diharapkan juga dapat bermanfaat dalam mengatasi harga karet yang rendah.

\section{Bahan dan Metode}

Penelitian dilakukan di perkebunan milik negara yang berlokasi di Jawa Tengah, pada bulan Februari - Desember 2016. Metode penelitian yang digunakan adalah metode survei. Sampel dipilih secara purposive pada 12 kebun berbasis tanaman karet. Parameter yang diamati pada penelitian ini adalah jenis tanaman kayu, harga jual kayu, dan biaya tanaman kayu yang diusahakan. Selanjutnya data dianalisis menggunakan metode secara deskriptif dan kuantitatif. Menurut Pasaribu (2012), suatu proyek dinilai layak melalui kriteria sebagai berikut :

- Net Present Value(NPV)

NPV merupakan nilai sekarang (present value) dari selisih antara benefit dengan biaya pada discount rate tertentu. Proyek dikatakan layak untuk dilaksanakan jika NPV $>0$.

$$
\begin{aligned}
& \mathrm{NPV}=\sum_{t=n}^{i=0} \frac{B_{t}-c_{t}}{(1+i)^{t}} \quad \text { atau } \\
& \mathrm{NPV}=\sum_{t=n}^{i=0}(\text { Net benefit })(D F) .
\end{aligned}
$$

Keterangan:

$B_{t}=$ Benefit pada tahun ket

$C_{t}=$ Cost pada tahun ket

Df $=$ Discount factor (bunga yang berlaku)

$\mathrm{N}$ = Waktu umur proyek

\section{- Gross B/C}

Gross B/C merupakan rasio antara jumlah Present Value Benefit (PVB) terhadap Present Value Cost (PVC). Jika Gross B/C nilainya $>1$, maka proyek layak dilaksanakan.
Gros $\mathrm{B} / \mathrm{C}=\frac{\sum P V(B)}{\sum P V(C)}$

IRR

IRR merupakan alat ukur kemampuan proyek dalam mengembalikan bunga pinjaman untuk membiayai suatu proyek. Jika IRR > tingkat bunga bank yang berlaku, maka proyek layak untuk dilaksanakan.

$\mathrm{IRR}=\mathrm{i}^{\prime}+\frac{N P V^{\prime}}{N P V^{\prime}-N P V^{\prime}}\left(\mathrm{i}^{\prime \prime}-\mathrm{i}^{\prime}\right)$

Keterangan:

$\mathrm{i}=$ tingkat bunga bank

Selain kriteria tersebut, juga ada $\mathrm{R} / \mathrm{C}$ ratio yang merupakan perbandingan antara penerimaan dengan total biaya. Menurut Suratiyah (2016), salah satu rumus yang digunakan untuk mengukur kelayakan finansial suatu usaha adalah : $\mathrm{R} / \mathrm{C}$ ratio, dimana kriteria usaha dinyatakan layak jika $\mathrm{R} / \mathrm{C}>1$ dan tidak layakjika $\mathrm{R} / \mathrm{C}<1$.

Keterangan :

$\mathrm{R}=$ penerimaan $=$ pendapatan $(\mathrm{Rp})($ revenue $)$

$\mathrm{C}=$ biaya total $(\mathrm{Rp})($ cost $)$

Penelitian ini juga dilakukan analisis uji sensitivitas finansial dengan skenario : (1) peningkatan biaya $10 \%, 20 \%$, dan $30 \%$, (2) penurunan harga $10 \%, 20 \%$ dan $30 \%$, (3) kombinasi skenario 1 dan 2. Analisis sensitivitas bertujuan untuk mengetahui persentasi peningkatan atau penurunan faktorfaktor tertentu yang dapat mengakibatkan perubahan dalam kriteria investasi yaitu dari layak hingga tidak layak(Gittinger, 2012).

Dalam menghitung analisis finansial tanaman kayu, menggunakan beberapa asumsi dasar sebagai berikut:

1. Harga jual kayu sengon Rp 173.000, jabon Rp 146.000, dan akasia Rp 85.000,-

2. Taksasi populasi yang dapat dipanen $85 \% \mathrm{x}$ $667=567$ pohon/ha (populasi menurut standar perusahaan). 
3. Biaya yang diperhitungkan adalah biaya investasi dan pemeliharaan selama masa tanam.

4. Biaya panen dan angkut ditanggung oleh pembeli, sehingga tidak diperhitungkan dalam analisis.

5. Discount factor $12 \%$ (suku bunga yang berlaku)

6. Umur ekonomi tanaman sengon 6 tahun, akasia 6 tahun, dan jabon 8 tahun.

\section{Hasil dan Pembahasan}

\section{A. Prospek Tanaman Kayu}

Pengembangan tanaman kayu sangat potensial, mengingat kebutuhan bahan baku perkayuan nasional setiap tahun mencapai 72 juta $\mathrm{m}^{3}$. Kebutuhan kayu yang terdiri dari industri sawmill sejumlah 30 juta $\mathrm{m}^{3}$, industri kayu lapis sejumlah 18 juta $\mathrm{m}^{3}$, dan industri pulp dan kertas sejumlah 17 - 25juta $\mathrm{m}^{3}$. Namun demikian budidaya tanaman hutan (kayu) termasuk kategori high risk high return, yakni dapat menghasilkan keuntungan yang sangat besar, namun juga memiliki resiko kegagalan. Kegagalan berupa kebakaran, penggembalaan liar, pencurian dan serangan hama penyakit (Mulyana \& Asmarahman, 2010). Menurut Badan Pusat Statistik (2015) kayu akasia merupakan kayu terbanyak yang diproduksi hingga mencapai 52,22\% dari total produksi kayu Indonesia, sedangkan kayu sengon hanya mencapai 5,89\% dan kayu karet hanya $1,14 \%$ seperti tertera pada Gambar 1 . Akasia berkembang dengan luas karena merupakan salah satu jenis kayu yang direkomendasikan ditanam dalam hutan tanaman industri (HTI). Menurut Nurwati et al. (2007) kementrian kehutanan sejak tahun 2015 membangun HTI dengan target 6,2 juta hektar sehingga menghasilkan 90 juta meter kubik per tahun. Salah satu jenis kayu HTI adalah Akasia Mangium (Acasia mangium Willd) yang merupakan pohon cepat tumbuh dan dapat dipanen dalam umur 6 - 7 tahun.

Gambar 2 menunjukkan produksi kayu bulat yang dihasilkan oleh HTI dan perum Perhutani. Trend produksi kayu bulat yang dihasilkan Perum Perhutani semakin menurun, sedangkan trend produksi yang dihasilkan HTI semakin meningkat. Hal tersebut menunjukkan bahwa pengelolaan produksi kayu bulat mulai terjadi pergeseran dari Perhutani ke HTI. Tanaman kayu tidak lagi didominasi oleh Perum Perhutani. Beberapa perusahaan perkebunan juga mulai membudidayakan kayu meskipun dengan luasan yang terbatas. Salah satu perkebunan berbasis karet yang juga membudidayakan tanaman kayu adalah Perusahaan XX yang berada di Jawa Tengah. Pada tahun 2016, perusahaan XX merupakan perusahaan berbasis karet namun juga memiliki tanaman kayu (campuran sengon, akasia, jabon, dan jenis lainnya) seluas $3.027 \mathrm{Ha}$.

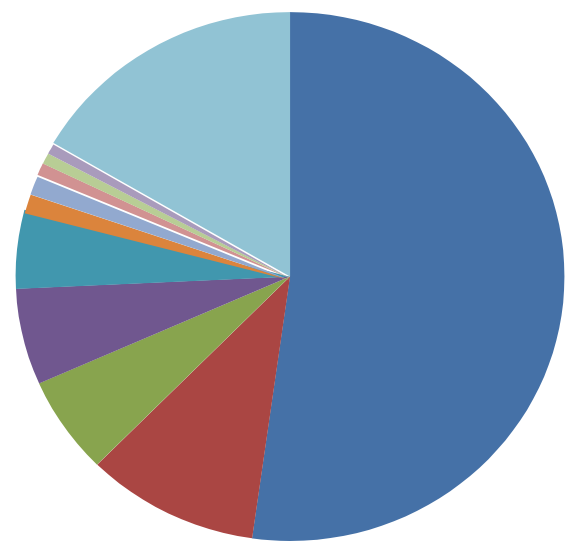

\begin{tabular}{|c|c|c|}
\hline Akasia & 口 & Jati \\
\hline Meranti 10\% & 口 & Kruing 1\% \\
\hline Rimba campuran $6 \%$ & 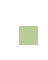 & Mahoni 1\% \\
\hline Sengon $6 \%$ & ш & Merbau 1\% \\
\hline Ekaliptus & - & Lainnya $16 \%$ \\
\hline
\end{tabular}

Sumber : (Badan Pusat Statistik, 2015)

Gambar 1. Produksi kayu bulat di Indonesia menurut jenisnya $\left(\mathrm{m}^{3}\right)$ tahun 2015 


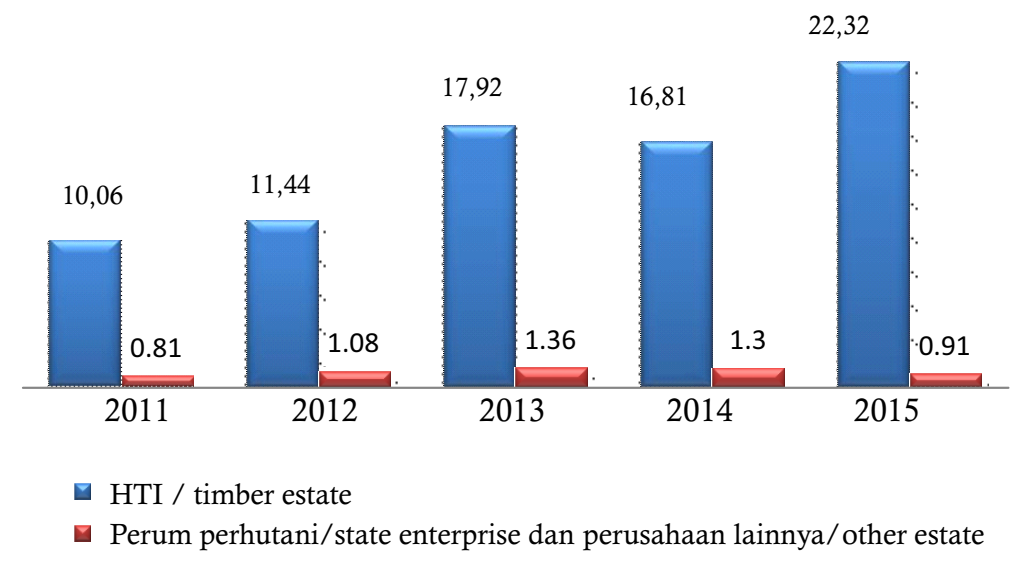

Sumber : (Badan Pusat Statistik, 2015)

Gambar 2. Produksi kayu bulat perusahaan pembudidaya tanaman kehutanan, 2011 - 2015 (juta m³)

\section{B. Tinjauan Tentang Kayu Sengon, Jabon, dan Akasia}

\section{Sengon}

Sengon memiliki dua nama latin yaitu Albizia falcate (L). Fosberg dan Paraseianthes falcataria (L). Nilsen. Umumnya di Jawa disebut dengan sengon laut. Sengon memiliki banyak manfaat yaitu sebagai pohon untuk rehabilitasi, pakan ternak, membantu menyediakan nitrogen dalam tanah, sebagai kayu olahan untuk membuat peti, papan penyekat, pengecoran semen dalam konstruksi, industri korek api, pensil, bahan baku industri kertas pulp, kayu lapis, kayu pertukangan, kerajinan seni bernilai tinggi dan kayu bakar(Hardiatmi, 2010).

Pada umumnya daur optimal tanaman sengon menggunakan daur biologis yang belum tentu menghasilkan keuntungan yang maksimal. Jika dihitung dengan metode maksimasi keuntungan dengan aturan Faustmann, yaitu mengelola tanaman sengon dengan sistem silvikultur tebang habis permudaan buatan, maka diperoleh hasil daur finansial tegakan hutan sengon pada bonita II, III dan IV adalah 7,6 dan 5 tahun. Daur ekologis sengon pada bonita II, III dan IV adalah 7,2, 6 dan 5 tahun. Kesamaan daur Faustmann dan biologis dapat disebabkan oleh tingginya tingkat pertumbuhan sengon (Indrajaya, 2013).

\section{Jabon}

Jabon merupakan tanaman asli Indonesia yang cepat tumbuh dan dapat dieksplorasi hasilnya selain bagian kayu, yaitu bunga, buah, daun, kulit kayu dan akar (Mansur \& Tuheteru, 2010). Ada dua jenis jabon yang ditanam masyarakat, yaitu jabon putih (Anthocephalus cadamba) dan jabon merah (Anthocephalus macrophyllus). Jabon merah umumnya dijumpai di Sulawesi dan Maluku dengan nama lokal samama. Kayu jabon memiliki kerapatan yang setara dengan mahoni, lebih tinggi dari jabon putih dan sengon. Karena kualitasnya yang baik, maka kayu baru dapat dipanen pada umur 7 - 10 tahun. Adapun saat ini jenis jabon yang ramai ditanam orang adalah jabon putih, yang memiliki umur tanam sekitar lima tahun. Jabon putih dapat dijadikan tanaman konservasi, bahkan tumbuh baik di lahan bekas tambang (Mansur, 2015). Jabon termasuk dalam famili Rubiaceae (suku kopikopian) dan memiliki banyak istilah, antara lain jabun, kelampayan, empayang, worotua, kadam, dan kawak. Jabon merupakan jenis komersial lokal yang bersifat intoleran dana dapat tumbuh dengan baik di areal bekas perladangan, semak belukar, dan hutan rawa yang tersebar luas di Indonesia. Pada umur 12 tahun, prosentase hidupnya mampu mencapai $57,7 \%$ dengan kerapatan tanaman 641 pohon/Ha dan MAI sebesar 19,05 $\mathrm{m}^{3} / \mathrm{ha} /$ th (Wahyudi, 2012). 
Kayu jabon merah memiliki karakteristik kayu lunak dengan berat jenis rendah hingga sedang. Dibandingkan dengan jabon putih dan sengon, kekuatan dan keawetan kayu jabon merah lebih baik. Hasil uji BBPBPTH Yogyakarta, jabon merah memiliki pertumbuhan yang sangat baik, yaitu pada umur 1 tahun sudah mencapai ketinggian 4,2 $\mathrm{m}$, diameter $5,7 \mathrm{~cm}$ dengan estimasi volum tegakan/ha sebesar $3,6 \mathrm{~m}^{3} /$ ha. Pertumbuhan tersebut jauh lebih tinggi daripada Acacia mangium dan Sengon (Falcataria moluccana). Keunggulan lain yang dimiliki jabon selain daya tumbuh yang sangat cepat, namun juga memiliki tingkat kelurusan yang tinggi, batangnya silinder dan cabang pada masa pertumbuhan akan rontok sendiri ketika pohon tumbuh meninggi sehingga tidak perlu dilakukan pemangkasan. Kayunya berwarna putih agak kekuningan tanpa terlihat serat yang sangat baik dapat dipergunakan untuk pembuatan kayu lapis (playwood), mebeler, bahan bangunan non konstruksi dan kayu gergajian. Usia optimal jabon adalah 12 tahun, namun sudah dapat ditebang pada usia $6-8$ tahun (Suwarto et al., 2014).

\footnotetext{
Akasia

Akasia (Acacia mangium Willd) dapat beradaptasi dengan baik pada berbagai jenis tanah dan kondisi lingkungan. Akasia dapat tumbuh dengan cepat meskipun di tanah bernutrisi rendah, bahkan tanah asam dan terdegradasi. Namun Akasia akan tumbuh kerdil dan kurus jika di bawah naungan (National Research Council, 1983). Akasia dapat mengalami kematian jika terkena kekeringan yang parah atau musim dingin yang berkepanjangan. Berdasarkan hasil ujicoba terhadap 46 jenis tanaman yang dilakukan oleh Departemen Kehutanan di Subanjeriji (Sumatera Selatan), diperoleh hasil bahwa Akasia yang paling cocok untuk tempat tumbuh marjinal, seperti padang rumput alang-alang(Arisman, 2003).

Kayu akasia dapat dimanfaatkan untuk pulp, kertas, papan partikel, krat serta kepingan-kepingan kayu dan berpotensi untuk kayu gergajian, molding, mebel, dan vinir. Kayunya memiliki nilai kalori sebesar 4.800-
}

$4.900 \mathrm{kkal} / \mathrm{kg}$, sehingga dapat digunakan untuk kayu bakar dan arang. Daunnya dapat dimanfaatkan sebagai pakan ternak, sedangkan cabang dan daun-daun keringnya sebagai bahan bakar. Pemanfaatan non kayu meliputi bahan perekat dan produksi madu. Serbuk gergajinya dapat dimanfaatkan sebagai substrat yang berkualitas bagus untuk produksi jamur yang dapat dikonsumsi (Soerianegara \& Lemmens, 1994).

\section{Gambaran Umum Wilayah Penelitian}

Lokasi penelitian terletak di Jawa Tengah yang tersebar di berbagai kabupaten dengan komoditas utama karet seperti disajikan pada Tabel 1. Luas total kebun adalah 29.646,88 Ha dengan dominasi tanaman karet sedangkan kayu mencapai luas 2.652,41 $\mathrm{Ha}$ atau 9\% (Gambar 3), yang tersebar di berbagai kabupaten di Jawa Tengah (Tabel 1).

\section{Analisis Finansial Tanaman Kayu}

Pada 12 kebun terdapat tanaman kayu berupa sengon, jabon, dan akasia yang memiliki umur panen bervariasi 6 hingga 8 tahun dalam satu siklus tanam. Analisis finansial tanaman kayu disajikan pada Tabel 2.

Dari ketiga jenis kayu, yang menghasilkan keuntungan tertinggi adalah sengon karena didukung oleh harga jual yang tinggi. Sedangkan nilai $\mathrm{R} / \mathrm{C}$ tertinggi adalah jabon senilai 4,53. Arti nilai $R / C$ 4,53 adalah dengan mengeluarkan biaya IDR 1 , akan menghasilkan penerimaan sebesar IDR 4,53. Biaya investasi jabon paling rendah dibandingkan yang lain, sehingga nilai $\mathrm{R} / \mathrm{C}$ nya paling tinggi namun memerlukan waktu paling lama (8 tahun) untuk memperoleh hasilnya.

Meskipun demikian,(Indrajaya \& Siarudin, 2013) berpendapat bahwa tanaman jabon yang dihitung berdasarkan daur finansial Faustmann dengan prinsip memaksimalkan keuntungan yang diperoleh pada tiap daur terjadi pada saat umur 6 tahun. Jika dihitung daur biologis jabon akan terjadi pada saat umur 5 tahun. Dengan demikian, tanaman jabon jika hanya diusahakan selama 6 tahun 
Tabel 1. Lokasi kebun berbasis karet

\begin{tabular}{cll}
\hline Nomor & Unit Kerja & Kabupaten \\
\hline 1 & Kebun A & Cilacap \\
2 & Kebun B & Cilacap \\
3 & Kebun C & Banyumas \\
4 & Kebun D & Pekalongan \\
5 & Kebun E & Pekalongan \\
6 & Kebun F & Batang \\
7 & Kebun G & Kendal \\
8 & Kebun H & Kendal \\
9 & Kebun I & Semarang \\
10 & Kebun J & Semarang \\
11 & Kebun K & Karanganyar \\
12 & Kebun L & Jepara \\
\hline
\end{tabular}

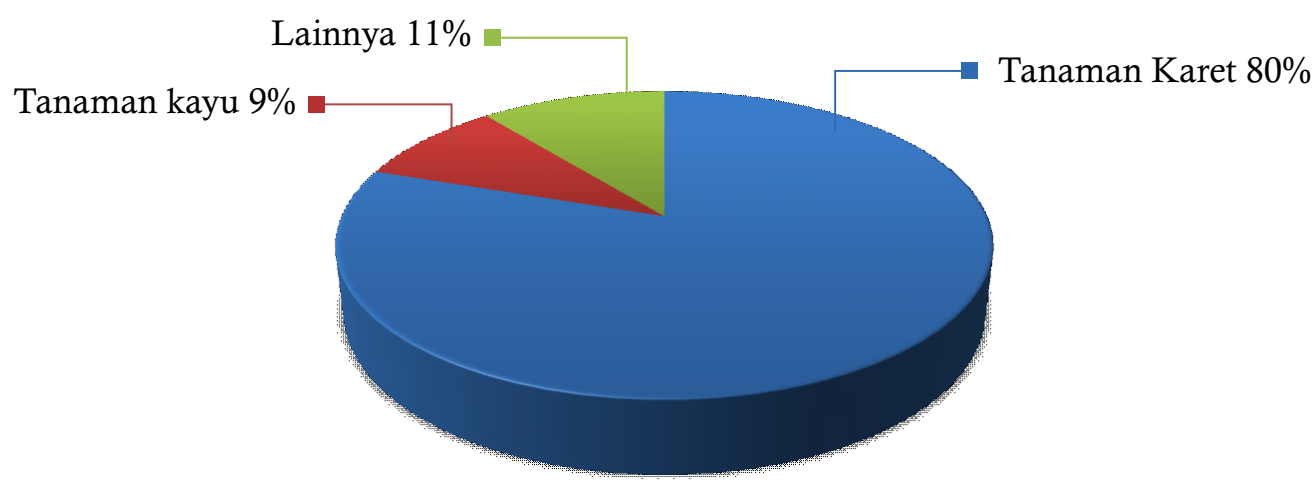

Gambar 3. Komposisi luas areal komoditas yang diusahakan

Tabel 2. Hasil analisis finansial tanaman kayu per hektar dalam satu siklus tanam

\begin{tabular}{lccccc}
\hline Jenis kayu & $\begin{array}{c}\text { Umur panen } \\
\text { (th) }\end{array}$ & $\begin{array}{c}\text { Biaya investasi } \\
(\mathrm{Rp} / \mathrm{ha})\end{array}$ & $\begin{array}{c}\text { Penerimaan } \\
(\mathrm{Rp} / \mathrm{ha})\end{array}$ & $\begin{array}{c}\text { Keuntungan } \\
(\mathrm{Rp} / \mathrm{ha})\end{array}$ & $\begin{array}{l}\mathrm{R} / \mathrm{C} \\
\mathrm{R} / \mathrm{C}\end{array}$ \\
\hline Sengon & 6 & 24.969 .968 & 98.082 .350 & 73.112 .382 & 3,93 \\
Jabon & 8 & 18.259 .734 & 82.774 .700 & 64.514 .966 & 4,53 \\
Akasia & 6 & 21.178 .698 & 48.190 .750 & 27.012 .052 & 2,28 \\
\hline
\end{tabular}


saja sudah menguntungkan. Adapun tanaman sengon, berdasarkan daur finansialnya sudah menguntungkan pada saat umur 7, 6 tahun dan 5 tahun.

Jika tanaman kayu ditanam disesuaikan dengan siklus tanam karet yaitu 25 tahun, maka selama periode 25 tahun, tanaman kayu akan menghasilkan keuntungan seperti dalam Tabel 3. Tabel 3 menunjukkan bahwa selama periode 25 tahun, tanaman kayu dapat ditanam sebanyak 3 - 4 kali dan akan diperoleh laba minimal Rp. 108.048.206/ha. Nilai tersebut mampu menjadi tambahan pendapatan kebun secara signifikan terutama di saat harga karet yang rendah.

\section{Kelayakan Finansial Tanaman Kayu}

Hasil analisis kelayakan finansial tanaman kayu dengan discount factor $12 \%$, diperoleh hasil ketiga tanaman kayu layak untuk diusahakan dengan kriteria sesuai dalam Tabel 4. Nilai NPV dan IRR tertinggi pada sengon, meski dengan nilai gross $\mathrm{B} / \mathrm{C}$ yang lebih rendah sedikit jika dibandingkan dengan tanaman jabon.

Tanaman sengon yang ditanam secara monokultur (Tabel 4) secara finansial, layak untuk dilaksanakan. Namun demikian, sengon juga dapat ditanam secara intercroping seperti hasil penelitian Siregar et al. (2007), tanaman sengon yang ditanam secara intercroping dengan nanas jika dihitung dengan suku bunga $17,53 \%$ akan menguntungkan dan pengambilan keputusan masyarakat dalam hal menanam dipengaruhi oleh jumlah kepemilikan lahan, biaya tanaman, harga jual kayu dan periode waktu yang diperlukan untuk memperoleh hasil panen.

\section{Analisis Sensitivitas}

Analisis sensitivitas dilakukan untuk memperoleh gambaran pada kondisi tekanan ekonomi berupa biaya naik $(10 \%-30 \%)$ dan harga turun $(10 \%$ - 30\%) seperti ditampilkan dalam Tabel 5 .

Tabel 5 menunjukkan bahwa tanaman kayu relatif tidak sensitif terhadap tekanan ekonomi berupa perubahan biaya dan harga jual. Hal tersebut teruji dalam kondisi biaya naik 10\%$30 \%$ dan harga turun $10 \%-30 \%$, baik secara terpisah maupun secara bersama-sama, semuanya mampu menghasilkan nilai $\mathrm{R} / \mathrm{C}$ ratio $>1$. Hasil nilai $\mathrm{R} / \mathrm{C}$ ratio $>1$ menunjukkan bahwa tanaman kayu layak secara finansial untuk dilaksanakan dan dikembangkan di perkebunan berbasis karet sebagai upaya mencapai optimalisasi lahan dan memperoleh tambahan pendapatan kebun selain tanaman karet.

Tabel 3. Keuntungan yang diperoleh selama periode 25 tahun

\begin{tabular}{|c|c|c|}
\hline Jenis kayu & Frekuens i tanam(kali) & Keuntungan (Rp/ha) \\
\hline Sengon & 4 & 292.449 .526 \\
\hline Jabon & 3 & 193.544 .898 \\
\hline Akasia & 4 & 108.048 .206 \\
\hline
\end{tabular}

Tabel 4. Hasil kelayakan finansial tanaman kayu

\begin{tabular}{|c|c|c|c|}
\hline Jenis kayu & NPV (Rp) & IRR(\%) & Gros B/C \\
\hline Sengon & 25.666 .924 & 34,52 & 2,37 \\
\hline Jabon & 17.164 .342 & 29,22 & 2,38 \\
\hline Akasia & 6.483 .561 & 21,57 & 1,42 \\
\hline
\end{tabular}

Keterangan : discount factor $12 \%$ 
Tabel 5. Analisis sensitivitas tanaman kayu dengan peubah biaya dan harga

\begin{tabular}{|c|c|c|c|c|c|}
\hline Peubah & Jenis kayu & $\begin{array}{l}\text { Biaya investasi } \\
\text { (Rp/ha) }\end{array}$ & $\begin{array}{l}\text { Pendapatan } \\
\text { (Rp) }\end{array}$ & $\begin{array}{c}\text { Laba } \\
\text { (Rp/ha) }\end{array}$ & $\mathrm{R} / \mathrm{C}$ \\
\hline \multirow[t]{3}{*}{ Biaya naik 10\% } & Sengon & 27.466 .965 & 98.082 .350 & 70.615 .385 & 3,57 \\
\hline & Jabon & 20.085 .707 & 82.774 .700 & 62.688 .993 & 4,12 \\
\hline & Akasia & 23.296 .568 & 48.190 .750 & 24.894 .182 & 2,07 \\
\hline \multirow[t]{3}{*}{ Biaya naik $20 \%$} & Sengon & 29.963 .962 & 98.082 .350 & 68.118 .388 & 3,27 \\
\hline & Jabon & 21.911 .681 & 82.774 .700 & 60.863 .019 & 3,78 \\
\hline & Akasia & 25.414 .438 & 48.190 .750 & 22.776 .312 & 1,90 \\
\hline \multirow[t]{3}{*}{ Biaya naik 30\% } & Sengon & 32.460 .959 & 98.082 .350 & 65.621 .391 & 3,02 \\
\hline & Jabon & 23.737 .654 & 82.774 .700 & 59.037 .046 & 3,49 \\
\hline & Akasia & 27.532.308 & 48.190 .750 & 20.658 .442 & 1,75 \\
\hline \multirow[t]{3}{*}{ Harga turun $10 \%$} & Sengon & 24.969 .968 & 88.274 .115 & 63.304 .147 & 3,54 \\
\hline & Jabon & 18.259 .734 & 74.497 .230 & 56.237 .496 & 4,08 \\
\hline & Akasia & 21.178 .698 & 43.371 .675 & 22.192.977 & 2,05 \\
\hline \multirow[t]{3}{*}{ Harga turun $20 \%$} & Sengon & 24.969 .968 & 78.465 .880 & 53.495 .912 & 3,14 \\
\hline & Jabon & 18.259 .734 & 66.219 .760 & 47.960 .026 & 3,63 \\
\hline & Akasia & 21.178 .698 & 38.552 .600 & 17.373 .902 & 1,82 \\
\hline \multirow[t]{3}{*}{ Harga turun $30 \%$} & Sengon & 24.969 .968 & 68.657 .645 & 43.687 .677 & 2,75 \\
\hline & Jabon & 18.259 .734 & 57.942 .290 & 39.682 .556 & 3,17 \\
\hline & Akasia & 21.178 .698 & 33.733 .525 & 12.554 .827 & 1,59 \\
\hline \multirow{3}{*}{$\begin{array}{l}\text { Biaya naik } 10 \% \text {, } \\
\text { harga turun } 10 \%\end{array}$} & Sengon & 27.466 .965 & 88.274 .115 & 60.807 .150 & 3,21 \\
\hline & Jabon & 20.085 .707 & 74.497 .230 & 54.411 .523 & 3,71 \\
\hline & Akasia & 23.296 .568 & 43.371 .675 & 20.075 .107 & 1,86 \\
\hline \multirow{3}{*}{$\begin{array}{l}\text { Biaya naik } 20 \% \text {, } \\
\text { harga turun } 20 \%\end{array}$} & Sengon & 29.963.962 & 78.465 .880 & 48.501 .918 & 2,62 \\
\hline & Jabon & 21.911 .681 & 66.219 .760 & 44.308 .079 & 3,02 \\
\hline & Akasia & 25.414 .438 & 38.552 .600 & 13.138 .162 & 1,52 \\
\hline \multirow{3}{*}{$\begin{array}{l}\text { Biaya naik } 30 \% \text {, } \\
\text { harga turun30\% }\end{array}$} & Sengon & 32.460 .959 & 68.657 .645 & 36.196 .686 & 2,12 \\
\hline & Jabon & 23.737 .654 & 57.942 .290 & 34.204 .636 & 2,44 \\
\hline & Akasia & 27.532 .308 & 33.733 .525 & 6.201 .217 & 1,23 \\
\hline
\end{tabular}

\section{Kesimpulan}

Usaha mencapai optimalisasi pemanfaatan lahan dan pendapatan usaha perkebunan karet dengan budidaya tanaman kayu merupakan pilihan yang tepat. Tanaman kayu jenis sengon, jabon, dan akasia secara finansial layak untuk dikembangkan dengan kriteria kelayakan NPV Rp 6 juta- Rp 25 juta, IRR 21\% - 34\%, gross $\mathrm{B} / \mathrm{C} 1,4-2,3$, dan $\mathrm{R} / \mathrm{C}$ ratio 2,2 4,5. Pada saat tekanan ekonomi biaya naik $10 \%-30 \%$ dan harga turun $10 \%-30 \%$, baik secara terpisah maupun bersama-sama juga masih layak dengan nilai $\mathrm{R} / \mathrm{C}>1$. Meskipun tanaman kayu sangat prospektif, sebaiknya perusahaan tetap menjaga keseimbangan proporsi kebun dengan tanaman lainnya. Tanaman kayu dapat ditanam secara monokultur dan intercroping dengan tanaman lainnya.

\section{Daftar Pustaka}

Arisman, H. (2003). The management aspects of industrial plantation in South Sumatra: a case of PT Musi Hutan Persada. Bogor, Indonesia: Badan Penelitian dan Pengembangan Kehutanan dan Japan International Cooperation Agency.

Badan Pusat Statistik. (2014). Proyeksi Penduduk menurut Provinsi, 2010-2035 (Ribuan). Diakses dari https:// www.bps.go.id/statictable/2014/02/18/1 274/proyeksi-penduduk-menurut-provinsi2010---2035.html.

Badan Pusat Statistik. (2015). Statistik Perusahaan Pembudidaya Tanaman Kehutanan 2015. Jakarta, Indonesia: Badan Pusat Statistik. 
Gittinger, J. P. (2012). Analisa Ekonomi Proyek Pertanian (2 ed.). Jakarta, Indonesia: UI Press-Jhon Hopkins.

Hardiatmi, J. S. (2010). Investasi tanaman kayu sengon dalam wanatani cukup menjanjikan. INNOFARM: Jurnal Inovasi Pertanian, 9(2), 17-21.

Indrajaya, Y. (2013). Penentuan daur optimal hutan tanaman sengon (Paraserianthes falcataria (L.) Nielsen) dengan metode Faustmann. Jurnal Penelitian Agroforestry, 1(1), 31-40.

Indrajaya, Y., \& Siarudin, M. (2013). Daur finansial hutan rakyat jabon di Kecamatan Pakenjeng, Kabupaten Garut, Jawa Barat. Jurnal Penelitian Hutan Tanaman, 10(4), 201211.

Krisnawati, H., Kallio, M., \& Kanninen, M. (2011). Acacia mangium Willd.: ekologi, silvikultur dan produktivitas: CIFOR.

Mansur, H. I. (2015). Bisnis \& Budidaya 18 Kayu Komersial. Jakarta, Indonesia: Penebar Swadaya Grup.

Mansur, H. I., \& Tuheteru, F. D. (2010). Kayu Jabon. Jakarta, Indonesia: Penebar Swadaya Grup.

Mulyana, D., \& Asmarahman, C. (2010). 7 Jenis Kayu Penghasil Rupiah. Jakarta, Indonesia: AgroMedia Pustaka.

Nasendi, B. D. (1984). Proyeksi Demand dan Supply Kayu Menjelang tahun 2000 dan 2020. di dalam : Kini Menanam Esok Memanen. Tulisan disajikan pada Lokakarya Pembangunan Timber Estate, Bogor.

National Research Council. (1983). Mangium and Other Fast-growing Acacias for the Humid Tropics: Report of an Ad Hoc Panel of the Advisory Committee on Technology Innovation. Diakses dari Board on Science and Technology for International Development, Office of International Affairs, National Research Council, in Cooperation with the Pusat Penyelidikan Hutan, Sandakan, Sabah,.
Nurwati, H., Hadi, Y., \& Setyaningsih, D. (2007). Sifat fisis dan mekanis sepuluh provenans kayu mangium (Acacia mangium willd) dari Patung Panjang Jawa Barat. Jurnal Ilmu dan Teknologi Kayu Tropis, 5(1), 7-11.

Pasaribu, A. M. (2012). Perencanaan proyek dan evaluasi proyek agribisnis. Makassar, Indonesia: Lily Publisher.

Pusat Penelitian Karet. (2016). Laporan Kajian pengaturan portofolio komoditas berbasis daya saing karet pada perkebunan karet lingkup perusahaan $x$. Diakses dari Pusat Penelitian Karet, Bogor.

Siregar, U. J., Rachmi, A., Massijaya, M. Y., Ishibashi, N., \& Ando, K. (2007). Economic analysis of sengon (Paraserianthes falcataria) community forest plantation, a fast growing species in East Java, Indonesia. Forest Policy and Economics, 9(7), 822-829.

Soerianegara, I., \& Lemmens, R. H. M. J. (1994). Plant resources of south-east Asia (Vol. 5). Wageningen, Netherlands: Pudoc Scientific Publishers.

Subari, D. (2014). Sustainabilitas hutan tanaman industri sengon (Albizia falcataria). Jurnal Riset Industri Hasil Hutan, 6(1), 9-14.

Suratiyah, K. (2016). Ilmu usaha tani. Jakarta, Indonesia: Penebar Swadaya.

Suwarto, Octavianty, Y., \& Hermawati, S. (2014). Top 15 tanaman perkebunan. Jakarta, Indonesia: Penebar Swadaya.

Wahyudi. (2012). Analisis pertumbuhan dan hasil tanaman Jabon (Anthocephallus cadamba). Jurnal Perennial, 8(1), 19-24.

Widyasari, T., \& Rouf, A. (2017). Pengaruh produktivitas terhadap harga pokok kebun karet di Jawa Tengah. Jurnal Penelitian Karet, 35(1), 93-102. 